\title{
A new species of the genus Purpuricenus Dejean, 1821 (Coleoptera: Cerambycidae) from the Caucasus
}

\author{
Новый виА рода Purpuricenus Dejean, 1821 \\ (Coleoptera: Cerambycidae) с Кавказа
}

\author{
M.L. Danilevsky

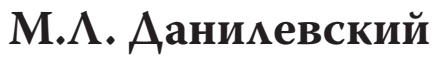

\begin{abstract}
A.N. Severtzov Institute of Ecology and Evolution, Russian Academy of Sciences, Leninsky prospect, 33, Moscow 119071 Russia. E-mail: danilevskyml@rambler.ru,danilevsky@cerambycidae.net

Институт проблем экологии и эволюции им. А.Н. Северцова РАН, Аенинский пр., 33, Москва 119071 Россия
\end{abstract}

Key words: Coleoptera, Cerambycidae, Cerambycinae, Purpuricenus, new species, Caucasus, Armenia, Azerbaijan, Georgia, Russia.

Ключевые слова: Coleoptera, Cerambycidae, Cerambycinae, Purpuricenus, новый виА, Кавказ, Армения, Азербайджан, Грузия, Россия.

Abstract. Purpuricenus caucasicola sp. n. is described from Krasnodar Region of Russia. The species is also distributed in Transcaucasia (Azerbaijan, Georgia) and probably in North Turkey. The taxon was recorded for the region before with a wrong name "Purpuricenus caucasicus". All similar taxa are also accepted as species: P. graecus Sláma, 1993, P. renyvonae Sláma, 2001, P. baeckmanni Danilevsky, 2007, P. neocaucasicus Rapuzzi et Sama, 2013.

Резюме. Purpuricenus caucasicola sp. n. описан из Краснодарского края России. ВиА также распространен в Закавказье (Азербайджан, Грузия) и, вероятно, в Северной Турции. Таксон ранее указывался Аля региона с неверным названием «Рurpuricenus caucasicus». Все близкие таксоны также рассматриваются как виды: P. graecus Sláma, 1993, P. renyvonae Sláma, 2001, P. baeckmanni Danilevsky, 2007, P. neocaucasicus Rapuzzi et Sama, 2013.

The name Purpuricenus budensis var. caucasicus Th. Pic, 1902 [Th. Pic, 1902] was accepted [Heyden et al., 1906: 517; M. Pic, 1912: 13) as an aberration of P. budensis (Götz, 1783). That status was proved by Plavilstshikov [1940: 568-569], who also described P. budensis $\mathrm{m}$ productus Plavilstshikov [1940: 569] - unavailable name. Both forms were figured by Plavilstshikov [1940: 568-569]. Miroshnikov [1984: 7, 9] identified a species from the Caucasus and Crimea as P. caucasicus and included in the taxon $P$. budensis $\mathrm{m}$. productus. The reasons for such identification were not published by him, but evidently it was made on the base of Plavilstshikov's [1940: 568-569] pictures and specimens from Plavilstshikov's collection without investigation of Th. Pic's type.

Purpuricenus caucasicus sensu Miroshnikov [1984] was accepted by Danilevsky and Miroshnikov [1985], Sláma [1993, 2001], Sláma and Slámová [1996], Althoff and Danilevsky [1997], Sama [2002], Özdikmen and Çaglar [2004].

Later the species was divided in two subspecies with the separation of Crimean populations as P. c. baeckmanni
Danilevsky, 2007 [Danilevsky, 2007: 38]. That taxon was originally segragated by J. Baeckman [see "Purpuricenus budensus tauricus Baeckm. in litt." by Plavilstshikov, 1940: 569], but not described. Sama [2010: 52] accepted the segregation of Crimean subspecies from Caucasian subspecies, but paradoxally joined it with Balcanian subspecies publishing new synonyms: P. caucasicus renyvonae Slama, $2001=$ P. c. baeckmanni Danilevsky, 2007. The natural situation was restored by Danilevsky [2010: 231] with separate publication of P. c. baeckmanni for Ukraine and P. caucasicus renyvonae for Bulgaria, Greece, Macedonia and Yugoslavia. It was supported by Miroshnikov [2009b: 64; 2012: 45] with atribution of the nominative subspecies to the Caucasus and Turkey.

The holotype of $P$. $b$. var. caucasicus was investigated by Sabbadini and Pesarini [1992], who agreed with the original position of the name inside $P$. budensis and published "Purpuricenus budensis caucasicus" as a Transcaucasian subspecies also distributed in allied territories of Turkey. The authors published the label of the holotype ("Helendorf"), but wrongly applied that old name to Armenian city Sevan. The elytral design of the holotype of $P$. $b$. var. caucasicus was published much earlier by Villiers [1978: 315, Fig. 1073], who also kept it inside $P$. budensis. The real nature of the holotype as P. kaehleri (Linnaeus, 1758) was identified by Rapuzzi and Sama [2013: 158], but the location of that specimen ("Helendorf") was wrongly determined (following Sabbadini and Pesarini) as "Elenovka, now Sevan". The true Helendorf was shown before by Miroshnikov [2012a: 45]: Khanlar (now Göygöl) in Azerbaijan.

The Caucasian species P. caucasicus sensu Miroshnkov [1984] (not Th. Pic, 1902) was joined by Rapuzzi and Sama [2013: 156, part.] to their P. renyvonae ssp. neocaucasicus Rapuzzi et Sama, 2013 distributed from Bolu, Kastamonu, Çorum and Tokat (Turkey) to the Caucasus (on the base of a single male from Tbilisi). So, Caucasian populations rested unknown to Rapuzzi and Sama, while Turkish populations were unknown to M. Danilevsky in all his publications. 
In fact many Purpuricenus taxa of the group are poorly investigated and known in a few specimens only. All are allopatric and usually more or less isolated, that allows to fabricate intentionally species taxa by selective joining similar populations. The modern level of knowledge permits to upgrade most of available names to species rank: P. graecus Sláma, 1993, P. renyvonae Sláma, 2001, P. baeckmanni Danilevsky, 2007, P. neocaucasicus Rapuzzi et Sama, 2013.

The Caucasian species is described bellow as new.

Abbreviations of collection:

AM - collection of A. Miroshnikov (Krasnodar, Russia);

JV - collection of J. Vartanis (Uherský Brod, Czech Republic);

NMP - National Museum Prague (Czech Republic);

ZMM - Zoological Museum of Moscow University (Russia).

\section{Purpuricenus caucasicola sp. n. (Color plate 11: 1-4)}

Purpuricenus (s. str.) budensis ab. caucasicus: Plavilstshikov, 1931: 80 - Caucasus.

Purpuricenus budensis ab. caucasicus: Plavilstshikov, 1940: 568-569, 769, part.; Heyrovský, 1955: 241, obr. 44 - 4; Panin, Săvulescu, 1961: 365; Kaszab, 1971: 202-203.

Purpuricenus budensis morpha productus: Plavilstshikov, 1940: 568-569, 769, part. (not available name) - Crimea, Caucasus, Transcaucasia, Syria; 1948: 118 - Transcaucasia; Heyrovský, 1955: 241, obr. 44 - 9-10; Panin, Săvulescu, 1961: 365.

Purpuricenus budensis ab. productissimus: Plavilstshikov, 1940: 569, 769 (not available name); Heyrovský, 1955: 241, obr. 44 - 10; Panin, Săvulescu, 1961: 365.

Purpuricenus budensis rasa productus: Panin, Săvulescu, 1961: 365 - "Crimeea, Caucaz, Transcaucazia şi Siria".

Purpuricenus budensis f. productus: Demelt, 1968: 65, 67, part. - "Krim, Kaukasicus, Transkaukasien"; Bernhauer, 1976: 124-125.

Purpuricenus budensis f. budensis ab. caucasicus: Demelt, 1968: 66, part.

Purpuricenus budensis f. productus ab. productissimus: Demelt, 1968: 67, part.

Purpuricenus budensis var. productus: Villiers, 1978: 315, part.

Purpuricenus budensis var. productissimus: Villiers, 1978: 315, part.

Purpuricenus caucasicus: Miroshnikov, 1984: 7, 9 - NorthWest Caucasus; 2000: 233 - Crimea, ? South and Central Europe, Adygea; 2007: 182, part. - Turkey (to the east from Kastamonu), Crimea, Caucasus (Kislovodsk, Gori, Mtskheta, Lagodekhi), Krinitsa environs in Krasnodar Region; 2009a: 791 - Belaya River valley in Adygea; 2009b: 64, part. - Crimea, Asia Minor, Caucasus (nominative subspecies): Khamyshki; 2012a: 44, part. - South Crimea, Asia Minor, Caucasus, ? Syria, ? North-West Iran; 20132b: 291, part. - South Crimea, Asia Minor, Caucasus; Danilevsky, Miroshnikov, 1985: 212-214, part. - Crimea, Caucasus, ? South and Central Europe; Sláma, 1993: 56; 2001: 225-227, 235-237, part. Sláma, Slámová, 1996: 123, part. - Yug. - Makedonia; Althoff, Danilevsky, 1997: 21, part. - ? South Europe (including Crimea); Zamotailov, Miroshnikov, 1997: 181; Sama, 2002: 55; 2010: 52, part.; Özdikmen, 2007: 247, 389, part. - "Europe (Crimea), Caucasus, Turkey [including Abant, Erzurum, Muğla and Bolu]"; 2008: 371; Nikitsky et al., 2008: 343 - Krasnodar Region; Bartenev, 2009: 175 - South and Central Europe, Greece, Bulgaria, Romania Ukraine (Crimea), ? Caucasus; Özdikmen, Çaglar, 2004: 57 -
Turkey; Nieto, Alexander, 2010: 31 - Europe; Sakenin et al., 2011: 5 - "Iran: East Azarbayjan province: Shabestar."

Purpuricenus budensis caucasicus: Sabbadini, Pesarini, 1992: 56, part. (the holotype label: "Helendorf") - Armenia, Turkey.

Purpuricenus caucasicus caucasicus: Danilevsky, 2007: 36 "Caucasus with Transcaucasia, Anatolia" (from Erzurum to Bolu); 2010: 231 - Azerbaijan, Armenia, Georgia, Turkey, South Russia; Miroshnikov, 2012a: 45 - nominative subspecies is distributed in the Caucasus and Asia Minor.

Purpuricenus budensis ? caucasicus: Özdikmen et al., 2009: 75.

Purpuricenus budensis productus: Özdikmen et al., 2009:

75 - "S Turkey".

Purpuricenus (s. str.) caucasicus caucasicus: Catalogue..., 2010: 198 - Azerbaijan, Armenia, Georgia, Turkey, South Russia; Miroshnikov, 2010: 249 - Adygea (Khamyshki).

Purpuricenus (s. str.) caucasicus: Miroshnikov, 2011: 558 ? Novorossiysk; 2012: 42 (Caucasian areal map), 44-45, Pl. 5.

Purpuricenus renyvonae ssp. neocaucasicus Rapuzzi et Sama, 2013: 156, part. - from Bolu, Kastamonu, Çorum and Tokat (Turkey) to the Caucasus (1 male) (Georgia).

Material. Holotype, $\mathrm{NW}$ Caucasus, Novorossiysk env., Dyurso, Orel Mt., 30.06-13.07.2009, A. Miroshnikov leg. (ZMM). Paratypes: $1 \hat{\text { ô }}$ with 4 labels: "Geok-Tapa, Caucasus, A. Schelkownikow", "Cotypus", "Purpuricenus budensis Gz. m. productus m. N. Plavilstshikov det., "Purpuricenus caucasicus Pic 그 A. Miroshnikov det. 1984" (ZMM); 1 , "Caucas. bor. Kislovodsk" (ZMM); 1 i with 4 labels: "Transcauc. Lagodechi, 9.07.[1]913, Mlokoss.," “Cotypus", “Purpuricenus budensis Gz. m. productus m. N. Plavilstshikov det., "Purpuricenus caucasicus Pic $\&$ A. Miroshnikov det. 1984” (ZMM); 1ㅇ, “Аагодехи, 17.07.1926, Ммокосевич” (Lagodekhi, 17.07.1926, Mlokosevich) (AM); 1ㅇ, "prov. Kuban, fl. Belaja, Chamyshki, 6.08.[19]33, Arnoldi” (ZMM); 19, Dzhubga, Krinitsa, 8.07.1975, A. Zamotailov leg. (AM); 1^, Georgia, Tsagveri, 15.07.1981, V. Dolin leg. (AM); 10^, "Gruzia, Tbilisi, Jezero Lisy [Lisi Lake], 29.6.1983, Dalihod leg." (JV); 10 , 19: NW Caucasus, Novorossiysk env., Dyurso, Orel Mt., 30.0613.07.2009, A. Miroshnikov leg. (AM); 19, NW Caucasus, Novorossiysk env., Malyi Utrish, 30.06-13.07.2009, A. Miroshnikov leg. (AM); 50, 4오, the same locality, 29.06-18.07.2011, A. Miroshnikov leg. (AM); $2 \widehat{\delta}, 2+$, NW Caucasus, Anapa env., Bolshoy Utrish, 20.06.2012, G. Shemberger leg. (AM); 1 3 , Krasnodar Region, $17 \mathrm{~km}$ south of Anapa, 2.07.2012, G. Shemberger leg. (JV); 19, Krasnodar Region, 17 km S.O. Anapa, 30.06.2014 (JV).

Purpuricenus neocaucasicus Rapuzzi et Sama, 2014: 10, 19 with labels: "Abant (Bolu), TR, 7.7.1994, col. Auvray N" (AM); 10 (Color plate : 5) with a label: "Turkva-Yaraligöz, Kastamonu prov., 10.7.2008, D.Loupanec leg." (JV); 10 with a label: "Yaraligoz TR (Kastamonu), 15.07.1996, leg. Auvray N." (NMP); 10 with a label: "Abant (Bolu) TR, 20.07.2000, leg. Auvray N." (NMP).

Description. Body relatively narrow; antennae in males usually surpassing elytra by $3^{\text {rd }}$ apical joints, often by $2^{\text {nd }}$, but sometimes by $1^{\text {st }}$ only; antennae in females usually reaching last elytral forth, sometimes hardly reaching last elytral third, very rare nearly attain elytral apex; $4^{\text {th }}$ antennal joint as long as $5^{\text {th }}$ or a little shorter, in males much longer than $1^{\text {st }}$ or in females about equal to $1^{\text {st }}$, and much shorter than $3^{\text {rd }}$ in males and females; thorax transverse, in males about as long as basal width or a little shorter; in females usually shorter than basal width, very rare about equal; lateral thoracic tubercles in males short, more or less obliterated, in females short, but usually distinct; prothorax convex, always with small shining central tubercle; basal pronotal half in males usually black up to central tubercle, very rare wider, only two males (Orel Mt. in Dyurso env. and Lisi Lake near Tbilisi) with about totally black pronotum bearing small reddish spots; pronotum in females much more red; posterior black area rarely reaching central tubercle; scutellum elongated; elytra parallelsided, in males from 2.3 to 2.5 times longer than basal width; in females from 2.1 to 2.3 times; black elytral area rather long, more or less parallelsided, slightly widened at apex, sometimes (1 male from Lisi Lake and 1 female from Lagodekhi) touching scutellum, anteriorly protruding and rounded, very rare emarginated; elytral apices can be widely rounded (especially in females), but often more or less truncated with distinct external angles; pygidium in males and in 

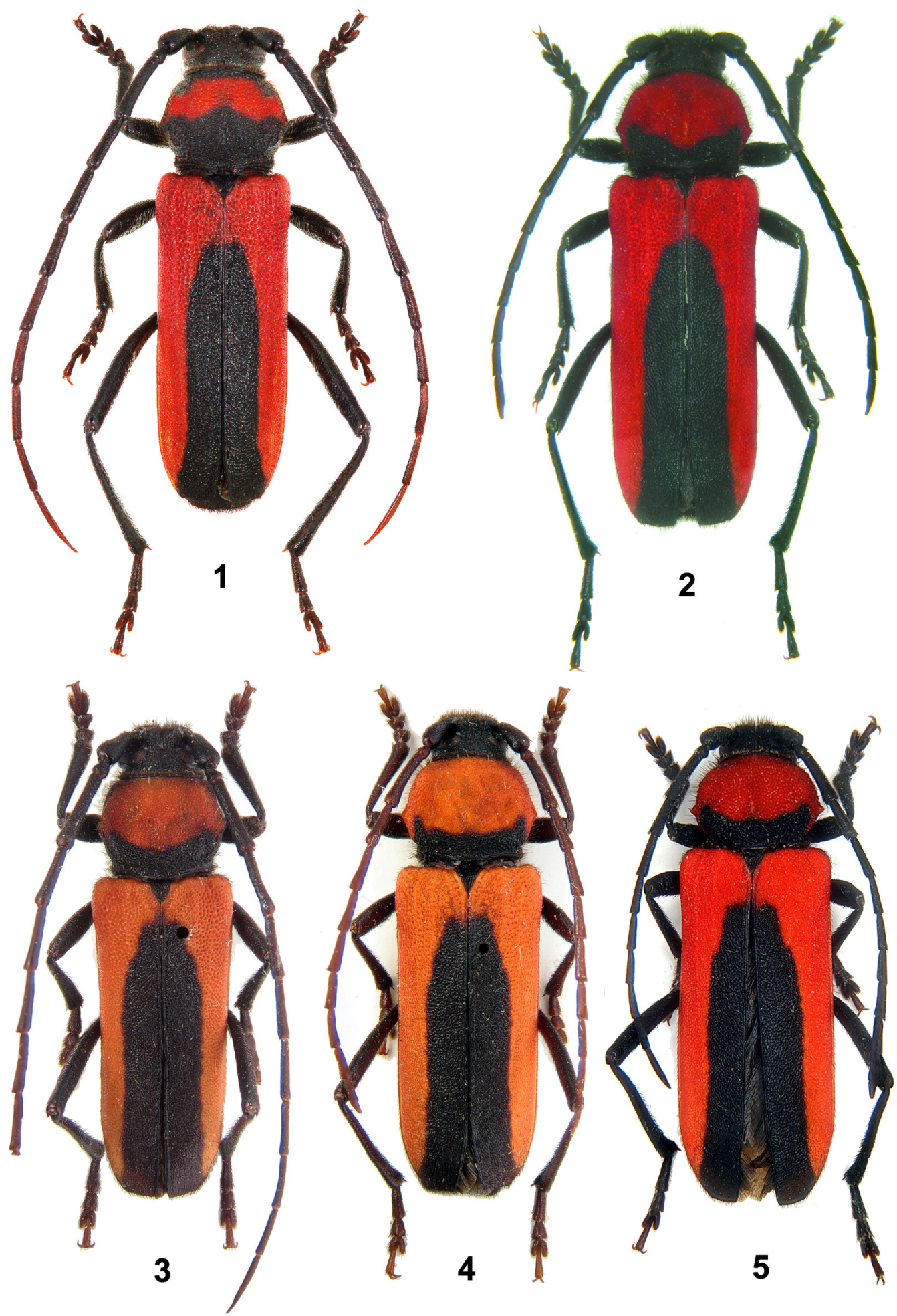

Figs 1-5. Purpuricenus, general view.

1-4 - P. caucasicola sp. n.: 1 -male, holotype, Novorossiysk env., Dyurso, Orel Mt. (photo by A.I. Miroshnikov and S.O. Kakunin); 2 - female, paratype from the same locality; 3 - male, paratype, Azerbaijan, Geok-Tapa; 4 - female, paratype, Georgia, Lagodekhi; 5 - P. neocaucasicus, female, Turkva-Yaraligöz, Kastamonu Prov., 10.7.2008, D. Loupanec leg.

Рис. 1-5. Purpuricenus, общий виА.

1-4 - P. caucasicola sp. п.самец, голотип, окрестности Новороссийска, Аюрсо, гора Орел (фото А.И. Мирошникова и С.О. Какунина); 2 - самка,

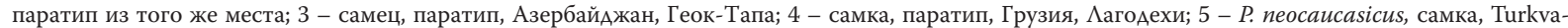
Yaraligöz, Kastamonu Prov., 10.7.2008, D. Loupanec leg. 
females slightly emarginated, postpygidium truncated; body length in males $12-15.8 \mathrm{~mm}$, in females $10.4-17.5 \mathrm{~mm}$; body width in males $3.7-4.6 \mathrm{~mm}$, in females $3.2-5.8 \mathrm{~mm}$.

Diagnosis. The new species is very close to P. neocaucasicus (Color plate 11: 5) distributed in Western and Central Anatolia, which is known to me after original description and 5 specimens only. I was not able to get more specimens. So, the distinguishing characters need to be better studied: in general $P$. caucasicola sp. $\mathbf{n}$. is distinctly narrower, with more red pronotum; anterior margin of black elytral area is rounded, very rare emarginated.

Distribution. Russia: the North Caucasus from about

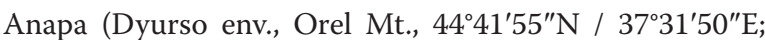
Malyi Utrish Cape, $44^{\circ} 42^{\prime} 29^{\prime \prime} \mathrm{N} / 37^{\circ} 27^{\prime} 30^{\prime \prime} \mathrm{E}$ ) to Kislovodsk and most probably further eastwards; another known localities are: Krinitsa $\left(44^{\circ} 23^{\prime} \mathrm{N} / 38^{\circ} 20^{\prime} 43^{\prime \prime} \mathrm{E}\right)$, Khamyshki $\left(600 \mathrm{~m}, 44^{\circ} 6^{\prime} \mathrm{N} / 40^{\circ} 8^{\prime} \mathrm{E}\right)$. Georgia: from Borzhomi and Tsagveri to Lagodekhi; another known localities are: Gori, Mtskheta, Khashmi $\left(41^{\circ} 46^{\prime} \mathrm{N} / 45^{\circ} 11^{\prime} \mathrm{E}\right)$. Azerbaijan: from Belokany $\left(41^{\circ} 44^{\prime} \mathrm{N} / 46^{\circ} 25^{\prime} \mathrm{E}\right)$ to Gyandzha and Agdash $\left(40^{\circ} 39^{\prime} \mathrm{N} / 47^{\circ} 28^{\prime} \mathrm{E}\right)$.

Remark. In fact the name "productus Plav." was accepted as available name of a subspecies long ago, because such publications as Panin and Săvulescu [1961] with "budensis rasa productus Plav." or Demelt [1968] of "budensis f. productus Plav." both with exact own separate areas are not more that publications of real subspecies. But ICZN [1999] from one side does not allow regarding old unavailable names newly published as "forma" available, and from other side does not mention "rasa" names at all (neither "natio"). The early publication of the name "productus Plav." (before 1985 - Art. 45.6.4.1.) as valid could make it available. But following explicitly to the Code it is necessary now to regard it unavailable.

\section{Acknowledgements}

I am very grateful to my friends and colleagues for providing me with the specimens for study: Aleksey Gusakov (Zoological Museum of Moscow University, Russia), Denis Kasatkin (Rostov-on-Don, Russia), Alexander Miroshnikov (Krasnodar, Russia), Janis Vartanis (Uherský Brod, Czech Republic).

\section{References}

Althoff J., Danilevsky M.L. 1997. A check-list of Longicorn beetles (Coleoptera, Cerambycoidea) of Europe. Ljubljana: Slovensko Entomolosko Drustvo Stefana Michielija. 64 p.

Bartenev A.F. 2009. Zhuki-usachi levoberezhnoy Ukrainy i Kryma [Longicorn-beetles of Left-Bank Ukraine and Crimea]. Kharkov: Kharkov National University. 405 p. (in Russian).

Bernhauer D. 1976. Eine neue Purpuricenusart aus Anatolien, sowie kritische Bemerkungen zur durchgesehenen Literatur (Coleoptera Cerambycidae). Nachrichtenblatt der Bayerischen Entomologen. 25 123-127.

Catalogue of Palaearctic Coleoptera. Vol. 6. Chrysomeloidea. (I. Löbl, A Smetana eds). 2010. Stenstrup: Apollo Books. 924 p.

Danilevsky M.L. 2007. Purpuricenus kaehleri (Linnaeus, 1758) and P. caucasicus Pic, 1902 (Coleoptera, Cerambycidae) in Caucasus. Studies and Reports of District Museum Prague-East, Taxonomical Series. 3: 31-42.

Danilevsky M.L. 2010. Additions and corrections to the new Catalogue of Palaearctic Cerambycidae (Coleoptera) edited by I. Löbl and A. Smetana, 2010. Russian Entomological Journal. 19(3): 215-239.
Danilevsky M.L., Miroshnikov A.I. 1985. Zhuki-drovoseku Kavkaza. Opredelitel. [Timber-Beetles of Caucasus (Coleoptera, Cerambycidae). Key]. Krasnodar. 419 p. (in Russian).

Demelt C. von. 1968. Eine neue Purpuricenus-Art aus Kleinasian. Entomologische Blätter. 64(2): 65-69.

Heyden L.F.J.D. von, Reitter E., Weise J. 1906. Catalogus Coleopterorum Europae, Caucasi et Armeniae rossicae. Berlin: R. Friedländer \& Sohn: $774 \mathrm{p}$.

Heyrovský L. 1955. Tesaříkovití - Cerambycidae. Fauna ČSR. Svazek 5. Praha: ČSAV: 347 p.

International Code of Zoological Nomenclature. Fourth Edition. International Comission on Zoological Nomenclature. 1999. London: The International Trust for Zoological Nomenclature: xxix + $306 \mathrm{p}$.

Kaszab Z. 1971. Cincérek - Cerambycidae. Fauna Hungariae. 106. Kötet 9. Coleoptera 4. Füzet 5. Budapest: Akadémia Kiadó: $283+17$ p

Miroshnikov A.I. 1984. Zhuki-drovoseki (Coleoptera, Cerambycidae) Severo-Zapadnogo Kavkaza [Timber-beetles (Coleoptera, Cerambycidae) of North-West Caucasus. PhD Abstract]. Kiev. 23 p. (in Russian).

Miroshnikov A.I. 2000. Purpuricenus caucasicus Pic, 1902. In: Krasnaya kniga Respubliki Adygeya [Red data book of the Republic of Adygea]. Maykop: Adygea: 233 (in Russian).

Miroshnikov A.I. 2007. Purpuricenus caucasicus Th. Pic, 1902. In: Krasnaya kniga Krasnodarskogo kraya (zhivotnye) [Red data book of Krasnodar Territory (Animals)]. Krasnodar: Center of information and economic development of press, TV and radio in Krasnodar Region: 182 (in Russian).

Miroshnikov A.I. 2009a. Contribution to the knowledge of the longicorn beetles (Coleoptera, Cerambycidae) of the Caucasus. 6. Notes on the distribution of some species with new data of their biology]. Entomologicheskoe obozrenie. 88(4): 787-796 (in Russian).

Miroshnikov A.I. 2009b. Species of animals, plants and fungi of Caucasian Reserve included or recommended to be included in Red data books. Family Cerambycidae - timber or longhorned beetles. In: Osobo okhranyaemye vidy zhivotnykh, rasteniy i gribov v Kavkazskom zapovednike. Trudy Kavkazskogo gosudarstvennogo prirodnogo biosfernogo zapovednika [Especially preserved species of animals, plants and fungi in Caucasian Reserve. Archives of Caucasian State Natural Reserve]. 19. Maykop: Kachestvo: 60-66 (in Russian).

Miroshnikov A.I. 2010. Family Cerambycidae - timber or longhorned beetles. In: Zhestkokrylye nasekomye (Insecta, Coleoptera) Respubliki Adygea (annotirovannyy catalog vidov). Seriya "Konspekty fauny Adygei” № 1 [Coleopterous insects (Insecta, Coleoptera) of Republic of Adygheya (annotated catalogue of species). Fauna conspecta of Adygheya. No 1.] Maykop: Adyghei State University Publishers: 239_ 263 (in Russian)

Miroshnikov A.I. 2011. Contribution to the knowledge of the longicorn beetles (Coleoptera, Cerambycidae) of the Caucasus. 7. Notes on the distribution of some species. Entomologicheskoe obozrenie. 90(3): $553-569+3$ plates (in Russian).

Miroshnikov A.I. 2012a. Contribution to the knowledge of the longicorn beetles of the Caucasus. 8. Genus Purpuricenus Dejean, 1821 (Coleoptera: Cerambycidae). Caucasian Entomological Bulletin. 8(1): 37-50, plates 4-5 (in Russian).

Miroshnikov A.I. 2012b. Purpuricenus caucasicus T. Pic, 1902. In: Krasnaya kniga Respubliki Adygea: Redkie i nakhodyashchiesya pod ugrozoy ischeznoveniya ob"ekty zhivotnogo i rastitel'nogo mira. Chast' 2. Zhivotnye [Red data book of Republic of Adygheya: Rare and threatened representatives of the regional fauna and flora. Part 2. Animals]. Maykop: Kachestvo: 291 (in Russian).

Nieto A., Alexander K.N.A. 2010. European Red List of Saproxylic Beetles. Luxembourg: Publications Office of the European Union. 45 p.

Nikitsky N.B., Bibin A.R., Dolgin M.M. 2008. Ksilofil'nye zhestkokrylye (Coleoptera) Kavkazskogo gosudarstvennogo prirodnogo biosfernogo zapovednika i sopredelnykh territoriy [Xylophilous beetles (Coleoptera) of the Caucasian State Biospheric Natural Reserve and adjacent territories]. Syktyvkar: Instutute of Biology of Komi Scientific Center of Ural Branch RAS. 452p. (in Russian).

Özdikmen H. 2007. The Longicorn Beetles of Turkey (Coleoptera: Cerambycidae). Part 1 - Black Sea Region. Munis Entomology \& Zoology. 2(2): 179-422.

Özdikmen H. 2008. The Longicorn Beetles of Turkey (Coleoptera: Cerambycidae). Part 3 - Aegean Region. Munis Entomology \& Zoology. 3(1): 355-436

Özdikmen H., Çaglar Ü. 2004. Contribution to the knowledge of Longhorned Beetles (Coleoptera, Cerambycidae) from Turkey Subfamilies Prioninae, Lepturinae, Spondylidinae and Cerambycinae. Journal of the Entomological Research Society. 6(1): 39-69. 
Özdikmen H., Turgut S., Güzel S. 2009. Longhorned beetles of Ankara region in Turkey (Coleoptera: Cerambycidae). Munis Entomology $\mathcal{E}$ Zoology. 4(1): 59-102.

Panin S., Săvulescu N. 1961. Coleoptera. Familia Cerambycidae (Croitori) Fauna Republicii Populare Romîne. Insecta. Vol. 10. Fasc. 5. Bucuresti: Editura Academiei Republicii Populare Romine. 524 p.

Pic M. 1912 Addenda et corrigenda au Catalogus Coleopterorum Europae. In: Matériaux pour servir à l'étude des Longicornes, $8^{\text {me }}$ cahier $2^{\mathrm{e}}$ partie. Saint-Amand (Cher): Imprimerie Bussière: 7-14.

Pic Th. 1902. Deux nouvelles variétés de "Purpuricenus" Fisch. L'Échange, Revue Linnéenne. 18 (209): 27 [mispaginated! the real pages 25-32 are inside No 208; volume erroneously given as 17].

Plavilstshikov N.N. 1931. Materials to the study of timber-beetles of the Caucasus and adjacent countries. Timber-beetles of the Caucasus, 1: Group Cerambycini (Coleopt., Cerambycidae). Biulleten' Muzeya Gruzii. 6(1930): 43-84 (in Russian).

Plavilstshikov N.N. 1940. Fauna SSSR. Nasekomye zhestkokrylye. T. 22. Zhuki-drovoseki (Ch. 2) [Fauna of the USSR. Beetles. Vol. 22. Cerambycidae (Part 2)] Moscow - Leningrad: Academy of Sciences of the USSR. 785 p. (in Russian).

Plavilstshikov N.N. 1948. Opredelitel zhukov-drovosekov Armenii [A Key for Longicorn Beetles of Armenia.]. Erevan: Academy of Sciences of Armenian SSR: 232 p. (in Russian).

Rapuzzi P., Sama G. 2013. Revision of the Purpuricenus interscapillatus species-group and allied taxa (Coleoptera, Cerambycidae). Fragmenta entomologica, Roma. 2012. 45(1-2): 143-171.

Sabbadini A., Pesarini C. 1992. Note su Purpuricenus budensis (Goese) e specie affini. Bolettino della Societa Entomologica Italiana, Genova. 124(1): 55-64.
Sakenin H., Samin N., Moemen Beitollahi S., Ezzatpanah S., Havaskary M., Rastegar J., Valizadeh A., Shakouri M.J. 2011. A study on the longhorn beetles (Coleoptera: Cerambycidae) from north-western Iran. Calodema. 143: 1-19.

Sama G. 2002. Atlas of Cerambycidae of Europe and the Mediterranean area. Vol. 1: northern, western, central and eastern Europe, British Isles and continental Europe from France (excl. Corsica) to Scandinavia and Urals. Zlín: Kabourek. 173 p.

Sama G. 2010. New Acts and Comments. Cerambycidae. In: Catalogue of Palaearctic Coleoptera. Vol. 6. Chrysomeloidea. (I. Löbl, A. Smetana eds). Stenstrup: Apollo Books: 49-58.

Sláma M. 1993. Zwei neue Taxa aus Griechenland - Purpuricenus graceus sp. n. und Brachyleptura maculicornis ondreji subsp. n. (Coleoptera, Cerambycidae). Folia Heyrovskyana. 1(6): 56-62.

Sláma M. 2001. Purpuricenus renyvonae sp. n. vom Balkan (Coleoptera: Cerambycidae). Biocosme Mésogéen. 2000. 17: 225-238.

Sláma M., Slámová J. 1996. Contribution to the recognition of Greek and Yugoslavian Longicorn beetles (Coleoptera, Cerambycidae). Biocosme Mésogéen. 1995. 12: 117-143.

Villiers A. 1978. Faune des coléoptères de France I. Cerambycidae. Encyclopédie Entomologique XLII. Paris: Editions Lechevalier. xxvii $+611 \mathrm{p}$.

Zamotajlov A.S., Miroshnikov A.I. 1997. Notes on "Red data book of Krasnodar Region. Insects". In: Integrirovannaya zashchita selskokhozyastvennykh kultur ot vrediteley, bolezney i sornyakov. Trudy Kubanskogo selskokhozyaystvennogo instituta [Integral protection of agricultural plants from pests, diseases and weeds. Archives of Kuban Agricultural Institute]. Iss. 356. Krasnodar: 178183 (in Russian). 